\title{
DAIRYING IN THE MOUNTAIN PASTURES IN THE JULIAN ALPS: HERITAGES, UTOPIAS AND REALITIES
}

ŠPELA LEDINEK LOZEJ

University of Udine

Department of Languages and Literatures, Communication, Education and Society

33100 Udine, Via Mantica 3

spela.ledinek@uniud.it
DOI: $10.17234 /$ SEC.27.1

Review article

Received: 1. 3. 2016.

Accepted: 24. 6. 2016.

This article is an open access article distributed under the terms and conditions of the CC BY-NCND 4.0 license.

This paper focuses on the history and the present state of dairying in the mountain pastures in the Eastern Alps and examines different recent measures for the certification of authenticity that aim to link traditional knowledge with sustainable development. Findings in this article are based on the intensive participant observation during the grazing seasons of 1998 and 1999, and on continuous sporadic fieldwork in different alps and conversations with different stakeholders up until today. The interpretation of these findings is based on and compared to the findings of Cristina Grasseni (2011) in the Italian North-Western Alps and of Sarah May (2014) in the German Alps.

Keywords: dairying, the Julian Alps, Alps (high altitude pastures and seasonal settlements), Alpine husbandry, protected designation of origin

\section{INTRODUCTION}

The aim of this article is to present the state of (traditional) dairying knowledge in the mountain pastures ${ }^{1}$ of the Julian Alps. In the first part, I will outline a brief history of Alpine husbandry, mountain pasture and dairying, i.e. the past elements and practices of which some are today considered (cultural) heritage. In the second part, I will discuss utopias and realities of contemporary Alpine pasture dairying practices that are confronted with issues of heritagization processes, oxymoronic sustainable

\footnotetext{
${ }^{1}$ In the text I will also use the term alp, which derives from the German term die Alp or die Alm and designates seasonal mountain pasture.
} 
development and EU Common Agricultural Policy. Findings in this article are based on the intensive participant observation during the grazing seasons of 1998 and 1999, and on continuous sporadic fieldwork in different alps and conversations with different stakeholders up until today. The interpretation of these findings is based on and compared to the findings of Cristina Grasseni (2011) in the Italian North-Western Alps and of Sarah May (2014) in the German Alps.

\section{HERITAGES}

In mountain environments, where agricultural activities are constrained by climatic effects of altitude, edaphic factors, scarcity of soil and steep gradients of the land, pastoralism has always been the most effective and dominant agricultural activity. Large expanses of grasslands, which ring the valleys between the tree line and the glaciers, could be made accessible for productive activities because of animals' ability to convert natural plants into nutritive food (Viazzo 1989:19). A combination of cultivation and herding, known as Alpine husbandry or Alpine agropastoral system, consisted of two (or more) spatially segregated spheres of production: fields and meadows near the village, and the alps, i.e. highaltitude pastures, which during the summer offered grazing for cattle, sheep and goats. In Slovenian, these alps are known as planine or planšarije, in Italian as alpi, alpeggi or malghe, in Friulian as mont, and in German as Almen or Alpen. The term is of Pre-Roman origin and designates not only pastures, but also huts, stalls and sometimes even dairies that were occupied by animals, herders and eventually dairymen in the summer months. Herders and cattle would not move directly from the village to the alps; instead, they would first transfer to granges in the higher meadows (rovt in Slovenian), which were used for grazing in combination with haying and perhaps some cultivation. After a couple of weeks, the livestock was moved to the lower alps, where the animals would stay from two to four weeks before they were transferred to the upper alps, where they would spend the peak season. In September, they would again descend to the lower alps, then to granges and finally to the villages (Cole and Wolf 1999:119-152; Netting 1981:19; Viazzo 1989:20).

Breeding and transhumance of livestock in the Alps had existed as early as prehistory and antiquity; its existence in the Eastern Alps was proven by 
archaeological finds as well as the etymology of toponyms and pasture and dairying terms (Cevc 2006:113-121; Mandl 2007: Novak 1961:126-128). The archaeological finds of vessels with holes (hypothesized to be cheese drainers) demonstrate that cheese-making technology in the Eastern Alps was already known in the Roman period (Cevc 2006:243-246); however, it has not been proven if cheese was in fact made in the mountain pastures. There are similar etymological legends in several Alpine regions explaining how shepherds were taught to make cheese by the savage man. They are supposed to have preserved the tradition that the Indo-European peoples of the Apennine peninsula and the Alps learnt how to make cheese from the early inhabitants (Cevc 2006:242; Grafenauer 1958:50-51; Matičetov 1972:87-94). Linguistic and legal history research supports the assumption that the (Romanized) inhabitants of the region already possessed dairying knowledge which they later transmitted to the newcomers in the Eastern Alps (Novak 1961:123-134).

Payments in cheese for hiring a mountain pasture during the summer season, which were documented in the written sources of the Patriarchs of Aquileia, prove that cheese had been processed from milk in mountain pastures of the Julian Alps as early as the 13th century (Cevc 2006: 248-249; Kos 1948:30-32; Melik 1950:97-101; Pascolini and Tessarin 1985:51-52; Vilfan 1996:228). ${ }^{2}$ Also the archaeological finds of torilo, i.e. a perforated cheese-draining piece of pottery, and shallow bowls from the alps attest to the existence of dairying at the end of the Middle Ages (Cevc 2006:251). It is believed that in that period, cheese was made from sour sheep milk (Bitterli-Waldfogel 1999:110).

Dairying became even more significant within the Modern Age physiocratic efforts of the Austrian Monarchy in the 19th century. Communal herding ${ }^{3}$ and land tenure - which were common for the upper alps, but not

\footnotetext{
${ }^{2}$ E.g. in the land registry of the Tolmin region it is documented that in 1338 the Kašina alp under the Krn Mountain, owned by the Patriarchs of Aquileia, was leased for the reimbursement of duties in the form of cheese, in Latin called caseus (Kos 1948:33).

${ }^{3}$ Two most evident advantages of communal herding were: (1) released manpower for agricultural tasks (by tending their livestock, a few individuals could relieve all the village households of many time-consuming chores, thereby enabling the rest of the working population to concentrate on agricultural activities), and (2) alleviation of the
} 
the lower alps and high meadows - were practiced by means of communal butter and cheese production. The basis for distribution of cheese or income was the quantity of milk produced after the cattle had been grazing on the mountain pasture on the measuring day (Ložar 1944:168-171). Members of the community later organised themselves in cooperatives. The predecessors of such cooperatives date back to the end of the 18th and early 19th century. In the second half of the 19th century, the Austrian Imperial Royal Ministry of Agriculture accelerated Alpine dairy farming, cattle in particular, and offered support and incentives for the improvement of the mountain pasture economy and the promotion of dairying (Valenčič 1990:31-42). The regional agricultural societies published professional literature (e.g. Trientl 1872; Wilhelm 1871), invited experts from Switzerland to teach the local cheesemakers about Swiss dairying (Povše 1870:18-17), and encouraged farmers to establish and join dairy cooperatives. These were established in order to improve the quality of production in accordance with strict rules regarding quantity, quality and hygiene of the delivered milk, and increase the profit (Valenčič 1990:32-37). In the late 19th century, the eventual individual production of butter, cheese from sour milk and cottage cheese was substituted by more profitable common dairying under the supervision of a hired skilled cheese-maker and sweet milk cheese production (Ledinek Lozej 2013a:67-77; Novak 1987:77-78, 1989; Taborra 2008: 26; Valenčič 1990:33-37). ${ }^{4}$

In the first half of the 20th century, competent state agencies proceeded to promote efficient dairying by publishing handbooks (Pevc 1925, 1926; Spiller-Muys 1926), founding dairy schools and, after World War I, carrying out the restoration of the alps (Marsano 1932; Tuma 1924). We can observe similar endeavours in the first decade after World War

problems of spatial disjunction between village fields and alps (Netting 1981:64-65; Viazzo 1989:23; Vincze 1980:397-397). Some of the authors pointed out other advantages of communal herding: e.g. care for pastures and their accessories (huts, stalls, enclosures, etc.). Communal herding is usually associated with communal tenure of the higher alps. By contrast, fields, meadows and other resources lying in lower-altitude production zones were subject to individual tenure (Peattie 1971:134; Viazzo 1989:24).

${ }^{4}$ Agricultural societies especially endeavoured to introduce the production of cheeses like Gruyère and Emmentaler (Mesar 1876:104). 
II. In the 1970s, dairying knowledge began to disappear in the alps as a result of different socio-economic factors; mostly due to the processes of urbanization and deagrarization, which led to the general abandonment of the Alpine husbandry, and, to a lesser extent due to the transport of milk by means of cisterns or milk pipes to the dairies in the valley. Whereas grazing in the alps has been preserved to a large extent, dairying - if we disregard individual processing of small amounts of milk and consider only processing of large quantities of milk - has been continuously preserved in only a few mountain pastures. ${ }^{5}$ Surprisingly, it has also been revitalised in some alps recently. ${ }^{6}$

\section{UTOPIAS AND REALITIES}

Searching for reasons for the preservation and revitalisation has led us to the crossroads between sometimes utopian aspirations of the European Union Common Agricultural Policy (CAP), implemented through national and (macro) regional measures, and the attempts of the local livestock farmers to survive in the new realities of a globalised world; between the European, national and regional policies and the revival and revitalisation of the past (also known as traditional) practices and products. These attempts to survive are, of course, not new; what is new is their active (or inactive) role in the labelling of products and wider glocalisation processes as well as heritagization practices.

\footnotetext{
${ }^{5}$ In the Slovenian part of the Julian Alps, these alps are: Krnica, Lom, Medrje, Podkuk, Polog, Pretovč, Razor, Stador and Sleme in the region of Tolmin; Božca, Hlevišče, Kašina, Matajur and Zaprikraj in the region of Kobarid; and Bitnje, Goreljek, Laz, Konjska dolina, Konjščica, Krstenica, Praprotnica, Uskovnica, Velo polje, and Zajamniki in the region of Bohinj (Ledinek Lozej 2013a:73). In the Italian Part of the Julian Alps, these Alps are: Sompdogna in the valley of Dogna, Lussari above Val Canale, Pecol under Montasio and Cuarnan above Gemona (Dreossi and Pascolini 2010:187-214; Chiopris and Pittino 2013). - For better readability, all toponyms from the Italian part are kept in the official, Italian form, although they also exist in Slovenian (and in some areas also in Friulian and German).

${ }^{6}$ In the Slovenian part of the Julian Alps, these mountain pastures are Duplje, Javornik, Kuhinja, Krnica, Leskovica, Zaslap and Zadnji Vogel (Ledinek Lozej 2013a:73), and in the Italian part these are Bieliga, Confin, Coot and Plan dei Spadovai (Dreossi and Pascolini 2010:189-212).
} 
Today, milk processing in the mountain pastures is encouraged by different EU CAP measures. The CAP - general guidelines are framed on the EU level, whereas detailed implementation varies and is dealt with on the national or regional levels - provides a set of financial subsidies to farmers in the form of market, income and rural development support (Nori and Gemini 2011:2). Remuneration of these agro-environmental measures is related to the amount of land managed by grazing activities regardless of the type of cattle (i.e. dairy or non-dairy). Another European and national measure of the agricultural quality policy, which encourages the production of cheese, is the provision of geographical indication labels, such as Protected Designation of Origin (PDO) or trademarks. This is based on the EU legal framework, which first came into force in 1992, and on the EU Regulation from 2012. The preambles to this Regulation cite consumer demand for quality foodstuffs and identify a number of goals, e.g. promotion of products with specific characteristics, particularly those from less-favoured rural areas, provision of clear information to consumers regarding product origin, increase of income for farmers in exchange for their genuine efforts in quality improvement, and the retention of population in rural areas (Regulation (EU) No 1151/2012:1-7). An application for a PDO is first made to the national authorities and, if found to be acceptable, forwarded to the European Commission for the final approval. In order to qualify for a PDO, the cheese must have the qualities and characteristics which are essential to its region of production; furthermore, it has to be produced, processed, and prepared exclusively within that region.

There are four regional hard cheeses that are traditionally produced in the mountain pastures of the Julian Alps and are awarded a PDO; three on the Slovenian and one on the Italian side. The Montasio cheese was originally produced in the mountain pastures under the the Montasio mountain chain in the Western Julian Alps (today's Italy). It was already mentioned on a price list dating back to 1775 . At the end of the 19th century, with the expansion of the cooperative dairies it spread also in the underlying valleys and neighbouring plains (Ghinetti 1885; Čotar 1988:42-95). Due to the efficient state and regional support it has been a protected trademark since 1955; moreover, since $1986,{ }^{7}$ it has featured a PDO on the national level and

\footnotetext{
${ }^{7}$ Two years after the establishment of the Consortium for the Protection of Montasio Cheese (Montasio 2012).
} 
since 1996 also on the European level (Regulation (EC) No 1107/96:6; Čotar 1988:42-95). A lot of energy has been invested in promotion and marketing of the Montasio cheese. In addition to featuring a protected trademark and PDO, it has been one of the four Italian products, ${ }^{8}$ chosen together with other European PDO products for promotion in the American market by the European Legends project (Consorzio 2016b). While the production of Montasio cheese is nowadays widespread in almost all of the Friuli Venezia Giulia region and in parts of the Veneto region, ${ }^{9}$ the symbolic value of the denomination has, as related by a livestock owner, vanished (Field records, July 15, 2016), and has become, as related by a cheesemaker, casual dairy cheese (Field records, July 16, 2016). Therefore, it is not surprising that today there are actually three varieties of certified Montasio cheese, namely the Montasio cheese PDO, the Montasio cheese PDO from the alp, which is "only produced from the milk of cows pastured in the alps under the Montasio" (Associazione 2012a), and the Montasio cheese PDO from only Italian Simmental breed (Bovolenta and Romanzin 2014:23). These alps have been owned by the Breeders Association of Friuli Venezia Giulia since 1936 and managed by the Montasio Alps Consortium, ${ }^{10}$ which have invested a lot into the development of tourism infrastructure, promotion of the alp, and organization of various events (Associazione 2012c, 2012d). However, cheese producers in the neighbouring alps are more inclined to produce the so called Alpine cheese (It. "formaggio di malga"):

"We produce Alpine cheese. The Montasio cheese you can get anywhere and anytime, whereas the Alpine cheese is produced only for three months in an alp; therefore, it has higher added value." (Field notes, 16 July, 2016)

\footnotetext{
${ }^{8}$ Beside Montasio cheese there were also San Daniele and Parma ham, and Grana Padano cheese (Consorzio 2016b).

${ }^{9}$ The production area of the Montasio cheese is as follows: the entire territory of the provinces of Udine, Pordenone, Gorizia and Trieste in the Friuli Venezia Giulia Region, and the whole territory of the provinces of Treviso and Belluno, as well as parts of the provinces of Venice and Padua in the Veneto Region. There are together 43 producers (Consorzio 2016a).

10 The Montasio Alps Consortium has also renamed the alps of Pecol, Parte di Mezzo and Larice into the Alp of Montasio (Associazione 2012b).
} 


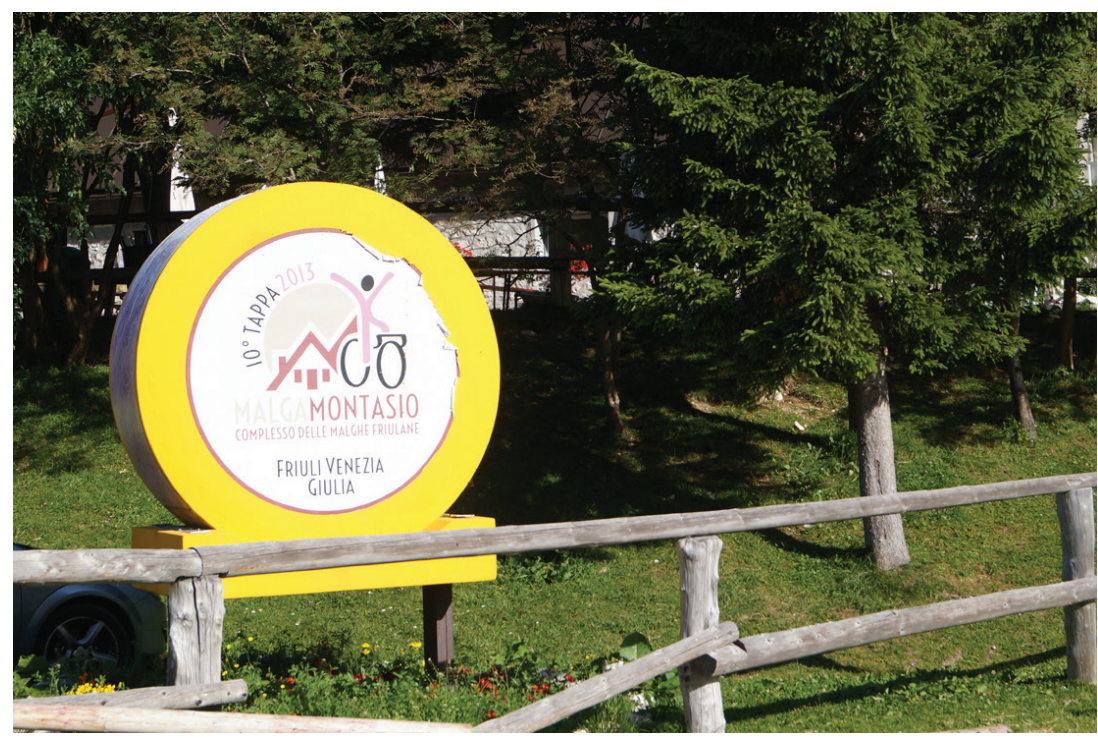

Picture 1: Promotion of the Montasio cheese in the Montasio alp. Photo by: Špela Ledinek Lozej, 2016.

The cheeses produced in the Slovenian part of the Julian Alps and awarded a PDO are the Tolminc (Regulation (EC) No 187/2012), the Bovec cheese (Regulation (EC) No 753/2012) and the Mohant cheese (Regulation (EC) No 1163/2013). ${ }^{11}$ As opposed to the large number of producers of the Montasio cheese, there are surprisingly few producers of PDO-labelled cheeses in Slovenia. In 2016 there were three producers of the Tolminc cheese, three of the Bovec cheese, and five of the Mohant cheese (Field notes,

11 There were also intensions to certify the Bohinj cheese, other variety of the regional cheese, which is technologically similar to the Emmentaler cheese. In 1999 the Bohinj cheese was registered as a trademark, as "a special type of Emmentaler cheese" (Bohinjska sirarna 2013). Those responsible for the rural development in the Triglav National Park - one of the two natural parks in the Julian Alps, the second being the Julian Prealps Natural Park in Italy - think, that it would be better to work on the national and European designation of origin instead of marketing a similar version of the original Swiss Emmentaler cheese (Field notes, May 11, 2012). However, a member of the Bohinj Cheese Society, which proposed the certification of the Mohant cheese and the author of its specifications, explains that they also wanted to certify the Bohinj cheese at the same time as the Mohant cheese, but the production of the Bohinj cheese at the time when the certification process began did not meet the PDO criteria (Field notes, July 15, 2016). 
July 15, 2016). The low number can be partially ascribed to the producers joining into consortia and partially to the unfamiliarity with PDO, as well as to general disinterest in it because of a technologically, administratively, and economically demanding certification process:

"It'svery complex! There are costs for paying the certification, not to mention additional red tape, paperwork! This is very strict!" (Field records, July 15, 2016).

None of the above mentioned scarce producers of PDO certified cheeses are located in the alps! $!^{12}$ What are the reasons for this aversion to certification among the cheesemakers in the alps?

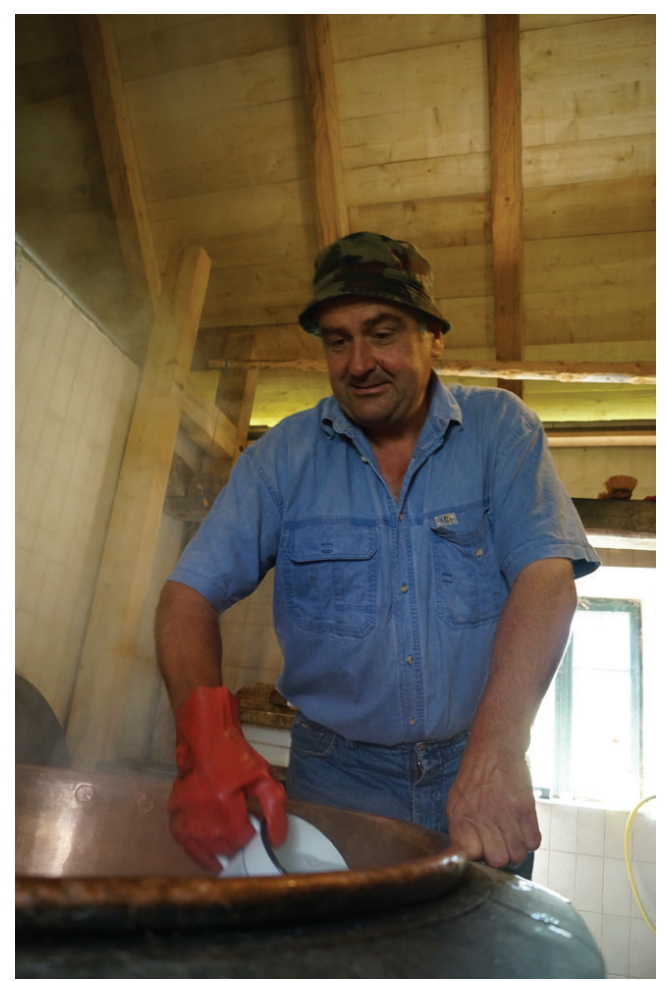

Picture 2: Cheesemaker Gregor Gartner washing the cauldron, Laz alp.

Photo by: Špela Ledinek Lozej, 2012.

The first reason is the presumable uniqueness and irreproducibility of the Alpine cheese. As it was stated by the cheesemaker from Gorjuše, cheese differs according to the particularity of the production area, of the alp and of the pasture, and even according to the predilection of the animals for certain herbs and not the others; therefore "the Alpine cheese cannot be consistent!" (Field records, August 22, 1998). There is a wide variety of the same product; ${ }^{13}$ therefore the producers can hardly follow the PDO requirements for standardization. Traditional technologies are soft, difficult

12 In 2015 the PDO Tolminc cheese was produced in the Kuhinja alp (Field records, June 21, 2015).

${ }^{13}$ For the argument see also Čotar (1988:89-93), Pascolini (2008b:44), Taborra (2008:2223) and Tonutti (2008:18-20). 


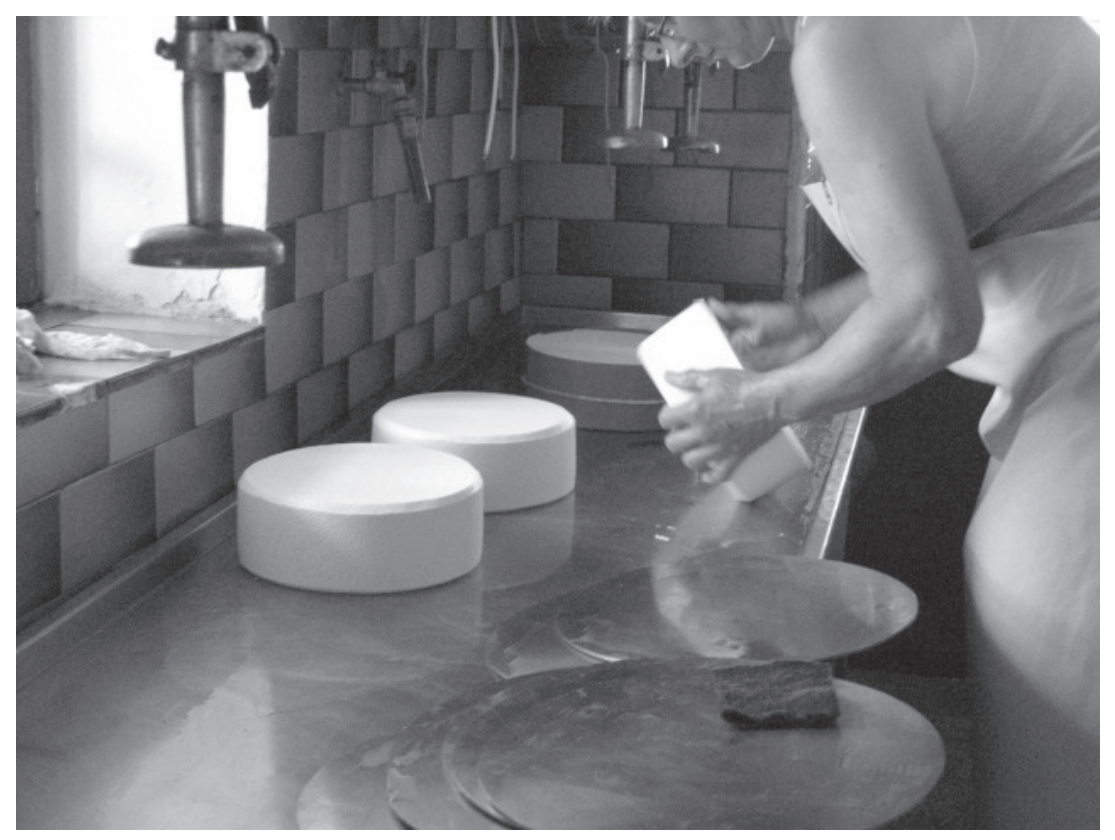

Picture 3: Marija Gaberšček turning round cheeses, Pretovč alp. Photo by: Špela Ledinek Lozej, 2011.

to keep under control and therefore do not always yield the expected results (Čotar 1988:43).

The second reason is probably the quantity of cheese produced in the alps. There is no market surplus, it is consumed at home, and when it comes to sales, the owners have no difficulty selling it all at the same price as the certified one. That is obvious from the statement of a cheesemaker from one of the Kobarid alps:

"We do not need to certify our cheese; it is the same as the Tolminc, we just don't have the right to sell it under that name. Anyways, we eat it all or sell it at the same price. So there is no difference and no need." (Field records, 21 June, 2015)

"Whereas some cheesemakers in the alps are producing traditional varieties of cheese, which are almost the same as the labelled ones, and are just not allowed to sell it officially under that name (which doesn't mean that they are not selling it unofficially), the others prefer to produce small-size semi-hard cheeses whose ripening is shorter 


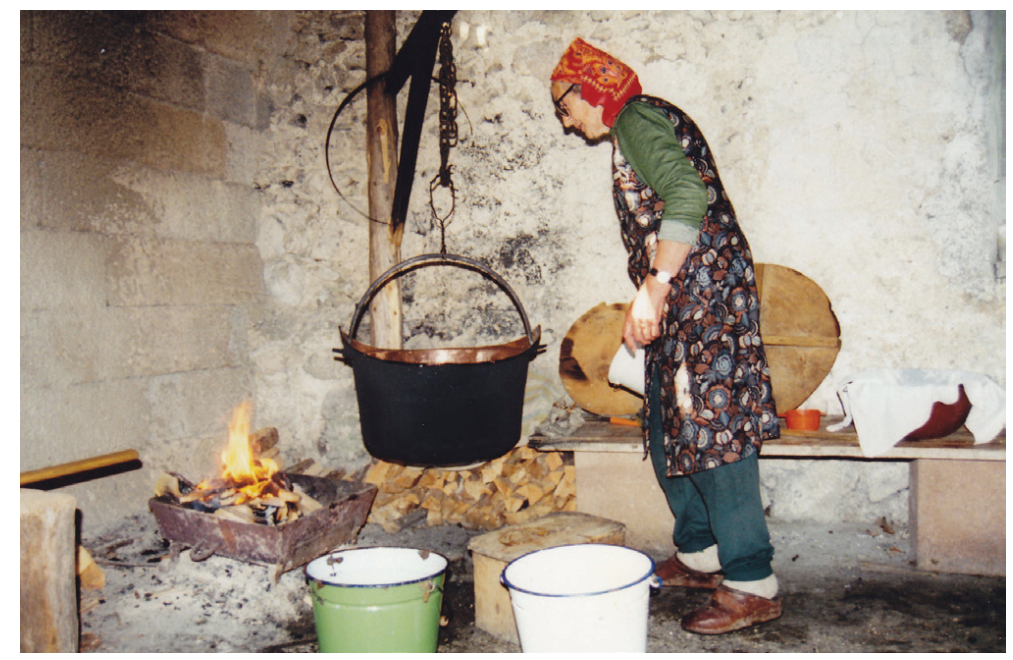

Picture 4: Anica Kovačič making cheese out of goat milk, Laz alp. Photo by: Špela Ledinek Lozej, 1998.

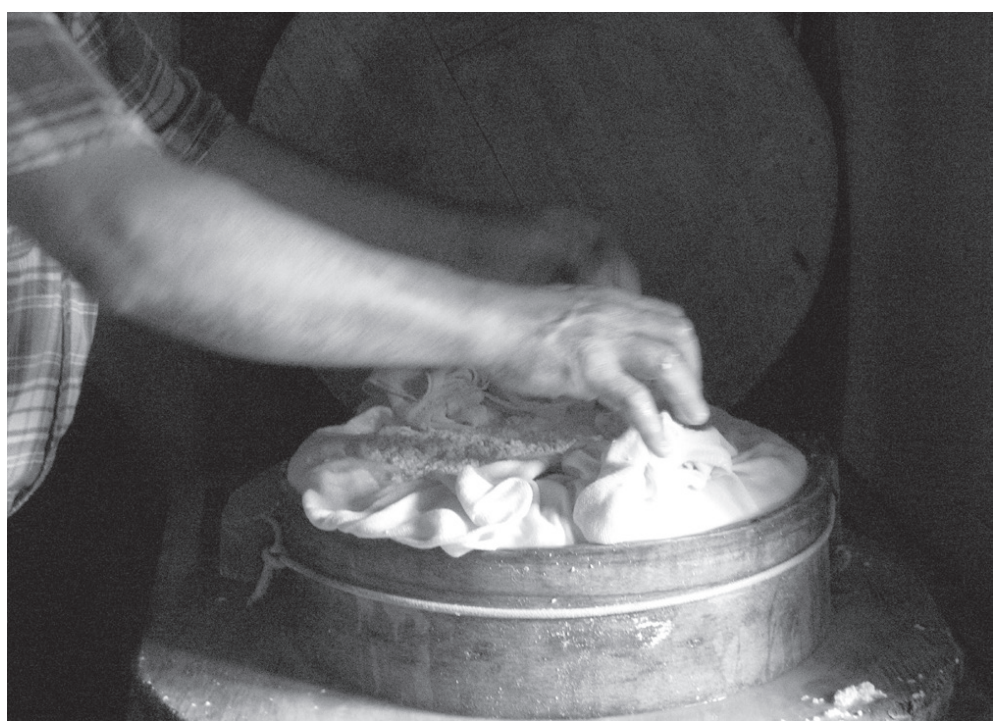

Picture 5: Cheese moulding in the wooden hoop, Laz alp. Photo by: Spela Ledinek Lozej, 2012.

and which are in demand by the tourists." (Field records, 10 October, 1998; 28 May, 2012; 16 July, 2016) ${ }^{14}$

${ }^{14}$ For greater detail on the area of Triglav National Park see Ledinek Lozej (2013b:60-61).

${ }^{15}$ It aims at fostering the distinctive value, origin, and special characteristics of the 
The fact that small scale producers have difficulties entering the quality system was also recognized by the European Commission's Directorate General for Agriculture and Rural Development. Therefore, they started to work on local agriculture and direct sales (local food, short food supply chains, direct sales, local food systems and mechanisms) and have recently developed several policy tools for short food chains and local food systems and a new labelling scheme (Tome 2013; Santini and Gomez y Paloma 2013). On the national and regional level these measures are implemented by the Slovenian Ministry of Agriculture, Forestry and Food under the Selected Quality-Slovenia label ${ }^{15}$ and by the Friuli Venezia Giulia Region under the Local Small Productions and recently under AQUA label. ${ }^{16}$ The complexity of branding is even greater because there are several other quality schemes: the municipal trademark From Bohinj (Turizem Bohinj 2014), the awards Specialities of Slovene Farms of the Chamber of Agriculture and Forestry Slovenia (Dobrote slovenskih kmetij 2015), the brands of regional development agencies, ${ }^{17}$ to name but a few. These brands and awards are easily accessible as a PDO, but seeing that their benefits are vague (Field records, July 15, 2016), their acquisition depend on the producer's own initiative. Furthermore, they are usually not economically beneficial and sustainable in the long run. ${ }^{18}$

The need for certification, especially the European and national PDO one, is therefore unclear. Some cheese producers consider it an opportunity for their promotion and guarantee of quality, as it is envisaged in the regulations, but not all of them meet the requirements or can cover the costs of certification. They understand it at best as symbolic or social

Slovenian products (Ministarstvo 2016).

16 They aim at enabling the production of safe foods without excessive red tape (Bianco, Pozzi and Tudorov 2015; Regione 2016).

${ }^{17}$ In 2008 the Idrija-Cerkno Development Agency and some other regional development agencies launched the Grape brand (under the LEADER project) with the aim of improving the visibility and value of agricultural produce and products, as well as handicraft products (Idrijsko-cerkljanska razvojna agencija 2015). It hasn’t flourished at all.

${ }^{18}$ This unsustainability is also the main reason why the Triglav National Park is reluctant to introduce the Triglav National Park quality label (Field records, May 11, 2012; July 15, 2016). 
capital and do not have any economic benefits of branding. Therefore, the cheesemakers in the alps (except the above mentioned producers of the PDO cheese in the Montasio alp) produce almost the same variety of cheese as the certified ones and sell it officially under a different name (or underthe-counter). However, other cheesemakers are more inclined to produce other varieties of cheese. In my opinion the cheeses which are not awarded PDOs and trademarks, are nevertheless authentic, if not even more so.

According to Cristina Grasseni (2011) food standardization

$\ldots$ is felt not only in economic terms, but also in symbolic and cultural terms. It is not only a movement towards more regulation and accountability, but also an increase in uniformity and in homogeneity, as opposed to diversity and variety... ${ }^{19}$

Despite the attempt of the certification process to emphasize the authenticity of cheese varieties, the process is at the same time one of standardization, unification, and homogenization due to the precise production protocols (e.g. quality control checks) that guarantee standard and consistent taste and appearance. We can agree with Cristina Grasseni (2011), who according to Robert Wilk (1995) claims that in the field of food production and consumption, global structures of common difference promote distinction and diversity, but only of certain types. Unfortunately for some representatives of European and national agrarian policy and fortunately for the rest - as it was explained by the cheesemakers and by other researchers (Čotar 2010; Pascolini 2008b:44, Taborra 2008:22-23; Tonutti 2008:18-20) - the Alpine cheese is hardly subjected to standardization.

\section{CONCLUSIONS}

The transition from the production of local varieties of dairy products aimed at local consumption to the production of market cheeses in the Julian Alps began as early as the end of the 19th century, when regional agricultural

\footnotetext{
${ }^{19}$ The article is an on-line version of the paper (GRASSENI, Cristina. 2011. "Re-inventing food: Alpine cheese in the age of global heritage". Anthropology of food, vol. 8. http://aof. revues.org/6819 (accessed 12 March, 2016)). There is no pagination. The text is divided into paragraphs and the quoted text is in the second paragraph.
} 
societies invited experts from Switzerland to teach the local cheesemakers about Swiss dairying. This was followed by endeavours of the qualified cooperative cheesemakers and accelerated by the introduction of nationally and EU acknowledged Protected Designations of Origin. On that timeline, we can - according to Cristina Grasseni (2011) - observe complex steps of reciprocal processes of progressive diversification and homogenization: from the use of sterile tools to the hygienization of the processing environment; from the auditing of production protocols (Strathern 2000) to certification; and from defining the specific geographical boundaries of typical production to their legal and marketing branding.

In this regard, I would like to question the real impact of the EU measures and regulations referring to the preservation of dairying knowledge in the alps. The overall aim of the EU Common Agricultural Policy (CAP) is to provide the European farmers with a reasonable standard of living and the consumers with quality food at fair prices as well as to maintain farming in all regions of the EU (Nori and Gemini 2011:2). However, as Gray (2002:31-32) already pointed out, the CAP usually sets conditions for farmers to produce (in their practices) in a specific rural locality in line with a version of locality set out in the CAP. However, that EU version - as can be seen from the example of producers of non-certified Tolminc-like cheese or the producers of local varieties of cheeses from the Bohinj alps - is not necessarily consistent with the rurality practised and envisaged by farmers. We can agree with Sarah May (2014:65) that geographical indications evoke governmentally initiated and dominated practises and that it is an essentially top-down undertaking. In our case they are favoured by the representatives of EU, national and regional agrarian policy, as well as by some regional development agencies and only a few producers. However, cheesemakers, who should be the target group of the European instrument, do not necessarily benefit from it.

We can see that the utopia of the actual construction or re-invention of food lies in the fact that just like in the case of sustainable development, a typical or an authentic product is a contradiction in terms, an oxymoron (Papa 2002). Typical products have thus been invented only recently in order to obtain the acknowledged geographical indications and market recognition. They are the result of two distinct and contradictory processes: 
on the one hand, market demand for organic and traditional food, and on the other, rediscovery of local products as a global phenomenon. Typical products converge in the general process of heritagization, in which past elements (e.g. traditional skills and food) are rediscovered and reinvented, both as a means of local development and as bearers of collective territorial identities (Grasseni 2011).

Whereas the Montasio cheese has outgrown its original slopes under the mountain chain of Montasio in the Julian Alps and, due to intensive state and regional support, has become the main regional dairies' brand, representative not only of the Friuli and Veneto territory (Pascolini 2008a:33-42), but - as it was demonstrated by the recent promotional campaign (Conzorzio 2016b) - also of the whole Italy and Europe, the representative range of the Bovec and Mohant cheese and Tolminc is more modest. Despite differences in the representative range and number of producers of the Montasio cheese and other PDO labelled cheeses there is no difference in the scope of the production of PDO labelled cheeses in the mountain pastures of the Julian Alps. Namely, the PDO labelled Montasio cheese is produced only in the Pecol (nowadays Montasio) alp, owned and managed by the offshoots of the Friuli Venezia Giulia Region, whereas the other mountain pasture cheesemakers prefer to produce other varieties of cheese. Therefore, with the exception of the Pecol (Montasio) alp, we can hardly see any impact of the European policy on the quality and quantity of dairying practices in the alps. Nonetheless, it does not mean that one cannot find tasty, quality and authentic cheeses in the alps of the Julian Alps!

\section{ACKNOWLEDGEMENTS}

These research results were obtained by means of funding from the European Social Fund under the Operational Programme 2014-2020, within Axis 3 - Education and Training, Specific Programme n. 26-Incoming and outgoing mobility of Researchers, TALENTS ${ }^{3}$ Fellowship Programme. 


\section{REFERENCES}

ASSOCIAZIONE ALLEVATORI DEL FRIULI VENEZIA GIULIA. 2012a. "Prodotti della malga". http://www.malgamontasio.it/index.php?option=com k2\&view=ite $\underline{\text { m\&layout}=i t e m \& i d=11 \& \text { Itemid }=22 \& l a n g=e n}($ accessed 16 July, 2016).

ASSOCIAZIONE ALLEVATORI DEL FRIULI VENEZIA GIULIA. 2012b. "Benvenuti in Malga Montasio". http://www.malgamontasio.it/index.php?lang=en (accessed 16 July, 2016).

ASSOCIAZIONE ALLEVATORI DEL FRIULI VENEZIA GIULIA. 2012c. "Appuntamenti in Malga Montasio 2016". http://www.malgamontasio.it/index. php?option $=$ com_k2\&view=item \&id=74:appuntamenti-in-malga-montasio2016\&Itemid=13\&lang=en (accessed 16 July, 2016).

ASSOCIAZIONE ALLEVATORI DEL FRIULI VENEZIA GIULIA. 2012d. "Altre iniziative". http://www.malgamontasio.it/index.php?option=com k2\&view=item

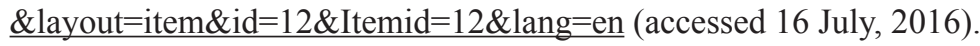

BITTERLI-WALDFOGEL, Thomas. 1999. "Mittelalterliche Alpwirtschaft in der Schweiz”. Beiträge zur Mittelalterarchäologie in Österreich, vol. 15:99-110.

BITUŠÍKOVÁ, Alexandra. 2013. "Slovak Milky Way: From Traditional Sheep Milk Production to Modest Local Gastronomy". In Traditional Food in the Central Europe: History and Change, ed. Tereza Pojarová. Prague: Institute of Ethnology of the Academy of Sciences of the Czech Republic, 46-64.

BOHINJSKA SIRARNA. 2016. “Zaščitni znak”. http://www.sir.si/zascitni znak.html (accessed 12 March, 2016).

CEVC, Anton. 2006. "Kdaj so začeli v planinah sirariti? Po sledeh arheoloških najdb in zgodovinskih virov do spoznanj o začetkih sirarjenja v planinah na Slovenskem". In Človek v Alpah: desetletje (1996-2006) raziskavo navzočnosti človeka v slovenskih Alpah, ed. Tone Cevc. Ljubljana: Založba ZRC, ZRC SAZU, 242-258.

CHIOPRIS, Giordano and Ennio PITTINO, eds. 2013. Malga che vai... Formaggio che trovi: Le malghe da latte della montagna friulana. Spilimbergo: Agenzia regionale per lo sviluppo rurale ERSA. http://www.ersa.fvg.it/tematiche/settore-lattierocaseario/malghe-da-formaggio-del-friuli-venezia-giulia/ERSA malga che vai formaggio_che trovi.pdf (accessed 11 July, 2016).

COLE, John W. and Eric R. WOLF. 1999 [1974]. The Hidden Frontier: Ecology and Ethnicity in an Alpine Valley. Berkeley - Los Angeles: University of California Press.

COMMISSION IMPLEMENTING REGULATION (EU) No 187/2012 of 7 March 2012 entering a name in the register of protected designations of origin and protected geographical indications (Tolminc (PDO)). Official Journal of the European Union L 69/5. http://eurlex.europa.eu/LexUriServ/LexUriServ.do?uri=OJ:L:2012:069:00 05:0006:EN:PDF (accessed 12 March, 2016). 
COMMISSION IMPLEMENTING REGULATION (EU) No 753/2012 of 14 August 2012 entering a name in the register of protected designations of origin and protected geographical indications (Bovški sir (PDO)). Official Journal of the European Union L 223/2. http://eur-lex.europa.eu/LexUriServ/LexUriServ.do?uri=OJ:L:201 2:223:0002:0003:EN:PDF (accessed 12 March, 2016).

COMMISSION IMPLEMENTING REGULATION (EU) No 1163/2013 of 7 November 2013 entering a name in the register of protected designations of origin and protected geographical indications (Mohant (PDO)). Official Journal of the European Union L 309/13. http://eur-lex.europa.eu/LexUriServ/LexUriServ.do?uri=OJ:L:2013:309 :0013:0014:EN:PDF (accessed 12 March, 2016).

COMMISSION REGULATION (EC) No 1107/96 of 12 June 1996 on the registration of geographical indications and designations of origin under the procedure laid down in Article 17 of Council Regulation (EEC) No 2081/92. Official Journal L 148. http://eur-lex.europa.eu/legal-content/EN/TXT/PDF/?uri=CELEX:31996R1107\& from=EN (accessed 12 March, 2016).

CONZORZIO TUTELA DEL FORMAGGIO MONTASIO. 2016a. "La zona di produzione". http://www.formaggiomontasio.net/code/10989/La-zona-diproduzione (accessed July 16, 2016).

CONZORZIO TUTELA DEL FORMAGGIO MONTASIO. 2016b. "Il Montasio DOP tra Le Leggende Europee". http://www.formaggiomontasio.net/it/14600/10985 (accessed 16 July, 2016).

ČOTAR, Danijel. 1988. "Il Montasio dalla A alla Z: Tradizione e Technologia”. In Montasio, un sapore infinito, ed. Giancarlo Ricci. Udine: Consorzio per la Tutela del Formaggio Montasio, 41-110.

ČOTAR, Danijel. 2010. Domače sirarstvo za zabavo in zares. Gorica: Goriška Mohorjeva družba.

DOBROTE SLOVENSKIH KMETIJ. 2015. "Vrste priznanj". http://www. dobroteslovenskihkmetij.si/index.php/ocenjevanja/vrste-priznanj\# (accessed 17 July, 2016).

EUROPEAN COMMISION. “Agriculture and rural development”. http://ec.europa.eu/ agriculture/quality/door/appliedName.html?denominationId=16101 (accessed 12 March, 2016).

GHINETTI, Guglielmo. 1885. Le latterie sociali del Friuli al concorso provinciale del maggio 1885: Relazione. Udine: Tipografia di Giuseppe Seitz.

GRAFENAUER, Ivan. 1958. "Zveza slovenskih ljudskih pripovedk z retijskimi”. Slovenski etnograf, vol. 11:49-68.

GRASSENI, Cristina. 2011. "Re-inventing food: Alpine cheese in the age of global heritage". Anthropology of food, vol. 8, no pagination. http://aof.revues.org/6819 (accessed 12 March, 2016). 
GRAY, John. 2002. "The Common Agricultural Policy and the Re-Invention of the Rural in the European Community". Socilogia Ruralis, vol. 40/1:30-52. http://media.library. ku.edu.tr/reserve/resfall04 05/INTL\%20533/INTL\%20533Gray.J.blacwell.pdf (accessed 12 March, 2016).

IDRIJSKO-CERKLJANSKA RAZVOJNA AGENCIJA. 2015. “GRAPE - Dobro pridelano doma". http://icra.si/index.php?id=56 (accessed 17 July, 2016).

KOS, Milko. 1948. Srednjeveški urbarji za Slovenijo: urbarji Slovenskega Primorja 2. Ljubljana: Akademija znanosti in umetnosti.

LEDINEK LOZEJ, Špela. 2011. Visokogorska planina Krstenica [Video]. Ljubljana: Avdiovizualni laboratorij ISN ZRC SAZU.

LEDINEK LOZEJ, Špela. 2013a. "Dairying in the Alpine pastures in Slovenia". In Traditional Food in the Central Europe: History and Change, ed. Tereza Pojarová. Prague: Institute of Ethnology of the Academy of Sciences of the Czech Republic, 65-80.

LEDINEK LOZEJ, Špela. 2013b. "Paša in predelava mleka v planinah Triglavskega narodnega parka: Kulturna dediščina in aktualna vprašanja”. Traditiones, vol. 42/2:49-68. http://isn.zrc-sazu.si/files/file/Traditiones/Traditiones 42 2 separati/51_pdfsam_Traditiones_42_2_TNP_web.pdf (accessed 17 July, 2016), https://doi.org/10.3986/Traditio2013420203

LOŽAR, Rajko. 1944. Narodopisje Slovencev, 1. Ljubljana: Klas.

MANDL, Franz. 2002. Almen im Herzen Österreichs: Dachsteingebirge, Niedere Tauern, Salzkammergut. Gröbming: Haus i. E.

MARSANO, Matteo. 1932. I pascoli alpini dell'alto e Medio Isonzo. Gorizia: Cattedra Ambulante d'Agricoltura per la Provicia di Gorizia.

MATIČETOV, Milko. 1972. "Elementi di cultura pastorale nei racconti del popolo sloveno". In Alpes orientales 6: Acta sexti conventus de ethnographia alpium orientalium tractantis, ed. Robert Wildhaber. München: R. Trofenik, 87-93.

MAY, Sarah. 2014. "Cheese, Commons and Commerce: On the Politics and Practices of Branding Regional Food". Ethnologia Europaea, vol. 43/2:62-77.

MELIK, Anton. 1950. Planine v Julijskih Alpah. Ljubljana: Slovenska akademija znanosti in umetnosti.

MESAR, Janez. 1876. "Iz poročila o delovanji in končnem računu prve Kranjske sirarske družbe "Bitnje" v Bohinju". Novice, vol. 14:104.

MINISTRSTVO ZA KMETIJSTVO, GOZDARSTVO IN PREHRANO. 2016. "Zaščitni znak Izbrana kakovost”. http://lokalna-kakovost.si/zascitni-znak-izbrana-kakovost/ (accessed 17 July, 2016).

MONTASIO. 2012. Montasio: Le nuove ricette: Ttradizione e innovazione: Un nuovo percorso di gusto. Cordropio: Vonsorzio per la tutela del formaggio Montasio. 
http://staticfiles.webarea8.ikon.it/montasio/flipviewerxpress.html (accessed 14 July, 2016).

NETTING, Robert McC. 1981. Balancing on an Alp: Ecological Change and Continuity in a Swiss Mountain Community. Cambridge: Cambridge University Press.

NOVAK, Anka. 1987. "Planinsko sirarstvo". In Bohinjski zbornik, ed. Jože Dežman. Radovljica: Skupščina občine, 73-84.

NOVAK, Anka. 1989. “Življenje in delo planšarjev v bohinjskih gorah”. Glasnik Slovenskega etnološkega društva, vol. 29:121-152.

NOVAK, Vilko. 1961. "Die Stellung des Alpwesens in Slovenien zwischen dem germanischen und romanischen Raume". In Alpes Orientales: Acta tertii conventus de ethnographia Alpinum Orientalium tractantis, 3, ed. Robert Wildhaber. Basel: Schweizerische Gesellschaft für Volkskunde, 123-134.

NORI, Syvia and Michele GEMINI. 2011. "The Common Agricultural Policy vis-à-vis European pastoralists: principles and practices". Pastoralism: Research, Policy and Practice, vol. 1/27. https://doi.org/10.1186/2041-7136-1-27

PAPA, Christina. 2002. "Il prodotto tipico come ossimoro: Il caso dell'olio extravergine di oliva umbro". In Frammenti di economie: Ricerche di antropologia economica in Italia, ed. Valeria Siniscalchi. Cosenza: Luigi Pellegrini Editore, 150-189.

PASCOLINI, Mauro. 2008a. "La percezione dei prodotti tipici: Una indagine quantitative". In Il formaggio: Saperi i sapori: I prodotti tipici come indicatori dell'identità del luogo, ed. Maro Pascolini. Udine: Università degli Studi di Udine, 33-42.

PASCOLINI, Mauro. 2008b. "Formaggi di Carnia unici e speciali? Alcune riflessioni finali”. In Il formaggio: Saperi i sapori: I prodotti tipici come indicatori dell'identità del luogo, ed. Maro Pascolini. Udine: Università degli Studi di Udine, 43-45.

PASCOLINI, Mauro and Nicoletta TESSARIN. 1985. Lavoro in montagna: Boscaioli e malghesi della regione alpine friulana. Milano: Istituto di socilogia internazionale Gorizia - Franco Angeli.

PEATTI, Roderick. 1936. Mountain Geography: A Critique and Field study. Cambridge: Harvard University Press. https://archive.org/details/mountaingeograph029782mbp (accessed 15 March, 2016).

PEVC, Anton. 1925. Mlekarstvo s črticami o živinoreji: Priročna knjiga za mlekarje, odbornike mlekarskih in živinorejskih zadrug ter za ljubitelje mlekarstva sploh. Ljubljana: Kleinmayr \& Bamberg.

PEVC, Anton. 1926. Sirarstvo. Gorica: Zadružna zveza.

POVŠE, Fran. 1870. "O mlekarstvu in sirarstvu s posebnim ozirom na razne razmere". Novice, vol. 3:17-18.

REGIONE FRIULI VENEZIA GIULIA. 2016. "Piccole Produzioni Locali”. http://ppl. regione.fvg.it/progetto/ (accessed 17 July, 2016). 
REGULATION (EU) No 1151/2012 of the European Parliament and of the Council of 21 November 2012 on quality schemes for agricultural products and foodstuffs. Official Journal of the European Union L 343/1. http://eur-lex.europa.eu/legal-content/EN/

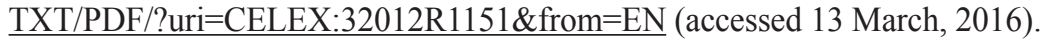

RENČELJ, Stanislav. 1995. Siri - nekdaj in zdaj. Ljubljana: Kmečki glas.

SANTINI, Fabien and Sergio GOMEZ y PALOMA, eds. 2013. Short Food Supply Chains and Local Food Systems in the EU: A State of Play of their Socio-Economic Characteristics. Luxembourg: Publications Office of the European Union. http:// ftp.jrc.es/EURdoc/JRC80420.pdf (accessed 14 April, 2016).

SPILLER-MUYS, Fran, ed. 1926. Planšarstvo in kmetijstvo na naših planinah. Ljubljana: Kmetijska tiskovna zadruga v Ljubljani.

STRATHERN, Marylin, ed. 2000. Audit Cultures. London: Routledge.

TABORRA, Marta. 2008. "I prodotti lattiero-caseari”. In Il formaggio: Saperi i sapori: I prodotti tipici come indicatori dell'identità del luogo, ed. Maro Pascolini. Udine: Università degli Studi di Udine, 22-32.

TOME, Branka. 2013. "EU Policy Tools for Short Food Chains \& Local Food Systems". Food from Here: Critical perspectives on Short Food Chains in Europe. Coventry University (UK), 3. 7. 2013. https://www.youtube.com/watch?v=CqMbh59VQVQ (accessed 14 April, 2016).

TONUTTI, Sabrina. 2008. "Biodiversità, formaggi, saperi e sapori nella storia e nelle testimonianze della ricerca etnografica". In Il formaggio: Saperi i sapori: I prodotti tipici come indicatori dell 'identità del luogo, ed. Maro Pascolini. Udine: Università degli Studi di Udine, 12-21.

TUMA, Henrik. 1924. "Naše planine”. Jadranski almanah 1924:76-94.

TURIZEM BOHINJ. 2014. "Bohinjsko B2B”. http://www.bohinj.si/si/b2b/bohinjsko (accessed 17 July, 2016).

VALENČIČ, Vlado. 1990. "Začetki organizacije našega mlekarstva”. Kronika, vol. 38/1-2:30-43.

VIAZZO, Pier Paolo. 1989. Upland communities: Environment, population and social structure in the Alps since the sixteenth century. Cambridge: Cambridge University Press.

VINCZE, Lajos. 1980. "Peasant animal husbandry: A dialectic model of technoenvironmental integration in agro-pastoral societies". Ethnology, vol. 19:387-403. https://doi.org/10.2307/3773148

VILFAN, Sergij. 1996. Pravna zgodovina Slovencev. Ljubljana: Slovenska matica.

WILHELM, Gustav. 1871. Planšarstvo. Gorica: C. kr. kmetijska družba Goriška.

WILK, Richard. 1995. "Learning to be local in Belize: Global systems of common difference". In Worlds apart: Modernity through the prism of the local, ed. Daniel Miller. London: Routledge, 110-133. 
Špela Ledinek Lozej

\section{MLJEKARSTVO NA PLANINSKIM PAŠNJACIMA JULIJSKIH ALPA: TRADICIJE, UTOPIJE I REALNOSTI}

Ovaj se rad bavi poviješću i sadašnjim stanjem mljekarstva na planinskim pašnjacima Istočnih Alpa te ispituje različite aktualne mjere potvrđivanja autentičnosti čiji je cilj povezati tradicionalna znanja s održivim razvojem. U ovom radu predstavljeni rezultati istraživanja nastali su intenzivnim promatranjem sa sudjelovanjem u razdobljima ispaše, tijekom 1998. i 1999. godine, te kontinuiranim terenskim radom u više navrata u različitim dijelovima Alpa, do današnjih dana, mahom kroz razgovore s raznim sugovornicima. Interpretacija podataka temelji se i komparira s ranijim nalazima Cristine Grasseni (2011) koja je istraživala u talijanskim sjeverozapadnim Alpama i Sarah May (2014) koja je svoja istraživanja provodila u njemačkim Alpama.

Ključne riječi: mljekarstvo, Julijske Alpe, Alpe (pašnjaci na velikim visinama), ratarstvo u Alpama, zaštićene oznake zemljopisnog podrijetla

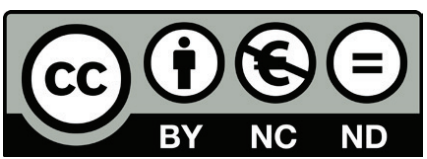

Articles published in this journal are Open Access and can be distributed under the terms and conditions of the Creative Commons license Attribution-NonCommercial-NoDerivatives 4.0 (http://creativecommons.org/licenses/by-nc-nd/4.0/) 
